Biol. Stud. 2020: 14(4); 69-84 • DOI: https://doi.org/10.30970/sbi.1404.639

www.http://publications.Inu.edu.ua/journals/index.php/biology

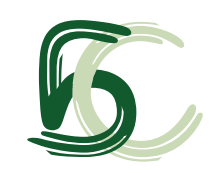

УДК: 597.6/.9:57.08

МЕТОДИ ТРЕКІНГУ ЗЕМНОВОДНИХ

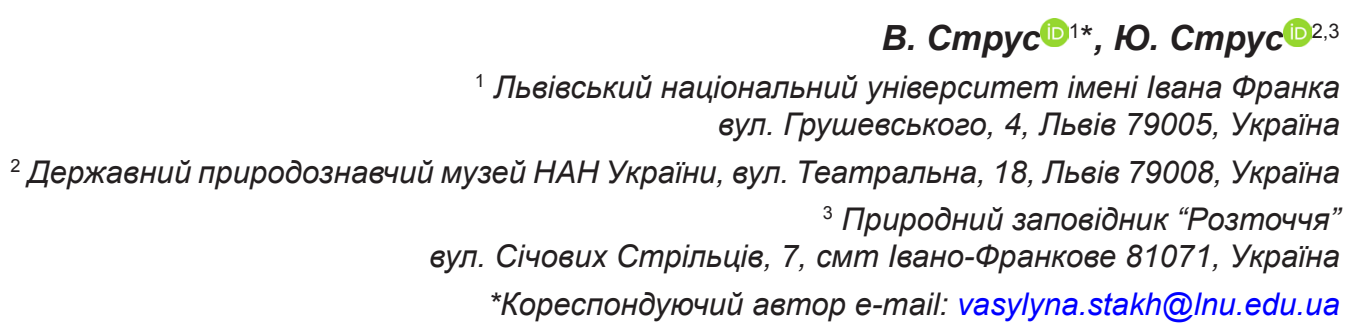

Strus V., Strus lu. Methods of amphibian tracking. Studia Biologica, 2020: 14(4); 69-84 • DOI: https://doi.org/10.30970/sbi.1404.639

Вступ. У статті представлено літературний огляд сучасних і найпоширеніших методів трекінгу земноводних. Земноводні $€$ найбільш чутливою групою тварин із $41 \%$ видів, які перебувають на межі вимирання. Тому дослідження просторових переміщень земноводних $є$ одним із найбільш актуальних завдань сучасної польової герпетології. Інформація про використання простору необхідна і для цілей практичної охорони вразливих видів амфібій, і для правильного проєктування територій ПЗФ, і для оцінювання потенційних загроз для окремих груп під час проєктування інфраструктурних об'єктів на кшталт доріг. Значного прогресу і популярності дослідження переміщень земноводних набули з другої половини XX, що пов'язано з розвитком радіоелектронних технологій, які дали змогу створити цілу низку приладів для автоматичного чи напівавтоматичного відстежування окремих особин тварин (трекінг). На жаль, досі більшість із цих методів залишаються досить дорогими, і в країнах, що розвиваються, використання деяких класичних методів і досі актуальне.

Результати. Розглянуто шість методів трекінгу земноводних: радіоізотопний метод, радіотелеметрію з можливістю автоматизування, пошук гармонічного напрямку, радіочастотний метод, використання фолуоресцентного порошку та нитковий трекінг. Кожен із методів дає змогу отримати більш точну і детальну інформацію про використання простору особинами виду. Більшість методів трекінгу побудована на використанні специфічної мітки, яку прикріплюють до тварини, щоб у подальшому стежити за нею. Різні типи міток виконуватимуть тотожні функції,

() 2020 V. Strus; Published by the Ivan Franko National University of Lviv on behalf of Біологічні Студії / Studia Biologica. This is an Open Access article distributed under the terms of the Creative Commons Attribution License (http://www.budapestopenaccessinitiative.org and Creative Commons Attribution 4.0 License), which permits unrestricted reuse, distribution, and reproduction in any medium, provided the original work is properly cited.

ISSN 1996-4536 (print) • ISSN 2311-0783 (on-line) • Біологічні Студії / Studia Biologica • 2020 • Том 14/№ 4 • С. 69-84 
в основі яких лежать різні принципи. Два з описаних методів не потребують використання міток і є відносно дешевшими, - це фрлуоресцентний порошок і нитковий трекінг. Також у статті подано чимало посилань на грантові програми чи ресурси для пошуку обладнання для того чи іншого методу трекінгу.

Висновок. У результаті проведеного літературного аналізу сфрормовано таблицю із лаконічною інформацією для точнішого вибору необхідного методу трекінгу залежно від потреб експерименту.

Ключові слова: земноводні, радіотелеметрія, флуоресцентний порошок, радіоізотопний трекінг, нитковий трекінг

\section{ВСТУП}

Дослідження просторових переміщень земноводних $є$ одним із найактуальніших завдань сучасної польової герпетології $[1,5,15,18,33,41]$. Розуміння закономірностей переміщень земноводних дає змогу глибше вивчити біологію їхніх добових і сезонних міграцій, зрозуміти, як саме простір використовується під час пошуку ресурсів, партнерів для розмноження чи для уникнення загроз. Інформація про використання простору необхідна і для цілей практичної охорони вразливих видів амфібій, для правильного проєктування територій ПЗФ чи для оцінювання потенційних загроз для окремих груп під час проєктування інфрраструктурних об'єктів, на кшталт доріг. Для останнього необхідно враховувати не тільки розміщення важливих локалітетів відтворення тварин, а і пролягання у просторі маршрутів їхніх добових і сезонних міграцій. У випадку із земноводними невдале проєктування дороги, що перетинатиме їхній міграційний маршрут, призведе до стрімкого падіння чисельності, навіть до вимирання локальної популяції, хоча важливі місця нересту або годівлі будуть збережені, що є класичним прикладом фрагментації середовища існування [50].

Раніше (до середини XX ст.) дослідження переміщень земноводних були складними для реалізації, оскільки жодних надійних методів для відстежування їхнього руху, крім прямого спостереження чи простого мічення, не було. Процес дослідження був трудомісткий, однак проміжні дані (інформація про перебування у просторі між пунктами повторних відловів) були недоступні. Відомо, що ефективність класичного мічення часто може бути дуже низькою, оскільки ймовірність контрольного відлову міченої особини для багатьох дрібних видів (і не тільки амфібій) є досить малою.

Значного прогресу і популярності дослідження переміщень земноводних набули з другої половини XX і на початку XXI ст., що пов'язано з розвитком радіоелектронних технологій, які дали змогу створити цілу низку приладів для автоматичного чи напівавтоматичного відстежування окремих особин тварин (трекінг). На жаль, досі більшість із цих методів залишаються досить дорогими (від 1500 \$), і в країнах що розвиваються, використання деяких класичних методів досі актуальне.

У цій статті ми розглянемо та порівняємо шість методів трекінгу земноводних: радіоізотопний метод, радіотелеметрію з можливістю автоматизування, пошук гармонічного напрямку, радіочастотний метод, використання фрлуоресцентного порошку та нитковий трекінг.

Основні методи трекінгу земноводних. Більшість методів трекінгу побудована на використанні специфічної мітки, яку прикріплюють до тварини для подальшого відстежування і пошуку цієї мітки. Різні типи міток виконуватимуть тотожні

ISSN 1996-4536 (print) • ISSN 2311-0783 (on-line) • Біологічні Студії / Studia Biologica • 2020 • Том 14/№ 4 • С. 69-84 
функції, в основі яких лежать різні принципи. Наприклад, мітка запису GPS також може бути обладнана УКХ-передавачем (УКХ - ультракороткі радіохвилі) (зазвичай мітки, які дають змогу використовувати GPS, пристосовані для трекінгу важких тварин (важче 2 кг), а не для земноводних). Мітки у різних методах відрізняються наповненням і принципом роботи й таким чином фрормують різні методи трекінгу [7].

Радіоізотопний трекіне (radioisotope tracking) - метод трекінгу тварин із використанням радіоізотопів. Це відносно старий метод (середина XX ст.) з використанням іонізуючого випромінювання, яке продукують радіонукліди. На той час метод був передовою технологією, оскільки сам детектор Гейгера-Мюллера розроблено у 1908 р. Тому для середини XX ст. це був оптимум для відстежування активності тварин [16]. Метод трекінгу потребував наявності детектора Гейгера-Мюллера, передавачів, наповнених радіоізотопом, і хірургічних умінь дослідника. Найчастіше радіоізотопні індикатори вибирали з урахуванням впливу радіоізотопу на організм тварини, тому для таких тварин як земноводні вміст самого радіоізотопу мав бути безпечним. Такий передавач прикріпляли ззовні, використовуючи трохи модифіковані кільця, подібні до орнітологічних кілець, але ця техніка не надто зручна для відстежування земноводних [61]. Альтернативою було вживляння мітки під шкіру [21] у спеціальному контейнері/капсулі (зазвичай зі свинцю, який часто додатково ще закривали пластиковою капсулою [24]). Період напіврозпаду радіоізотопу мав бути коротким, на випадок втрати твариною детектора для уникнення згубної дії на середовище, та достатнім для відстежування тварини протягом експерименту. У табл. 1 наведено періоди напіврозпаду радіонуклідів, які найчастіше використовували. Після вивільнення тварини дослідник міг знайти їі за допомогою детектора радіоактивного випромінювання (наприклад, лічильник Гейгера-Мюллера). Такий тип трекінгу використовували для пошуку гнізд дрібних ссавців, а в нашому випадку - нерестилищ, кормових біотопів і місць гібернації земноводних [24]. Також таким методом відстежували добову активність тварини [6]. Деякі автори стверджували, що неправильно підібрана кількість радіонукліду призводить до смерті тварини від опромінення $\gamma$-променями $[45,60]$, проте водночас для кращого виявлення особини потрібна вища доза радіонукліду. Саме тому цей метод поєднував баланс між негативним впливом на тварину й ефективністю подальшого виявлення поміченої особини. Радіоізотопний трекінг був досить трудомістким, оскільки необхідно було достатньо близько підійти до особини, аби детектор виявив високоенергетичні заряджені частинки радіоізотопу. Часом метод поєднували з використанням флуоресцентного порошку для швидкого пошуку тварини [39].

\section{Таблиця 1. Найчастіше використовувані радіонукліди, необхідні для виготовлення мітки, та їхні періоди напіврозпаду}

Table 1. The most common radioisotopes which were used for tags preparing and their half-time periods

\begin{tabular}{|c|c|c|c|c|c|c|}
\hline Радіонуклід & ${ }^{60} \mathrm{Co}$ & ${ }^{198} \mathrm{Au}$ & ${ }^{131} \mid$ & ${ }^{124} \mathrm{Sb}$ & ${ }^{45} \mathrm{Ca}$ & ${ }^{182} \mathrm{Ta}$ \\
\hline Період напіврозпаду & 5,3 роки & 2,7 доби & 8 діб & 60 діб & 165 діб & 115 діб \\
\hline
\end{tabular}

Метод радіоізотопного трекінгу тепер не використовують через забруднення середовища радіоізотопами, шкідливий вплив на об'єкт дослідження та дорогі ліцензії, необхідні для такої роботи [36].

ISSN 1996-4536 (print) • ISSN 2311-0783 (on-line) • Біологічні Студії / Studia Biologica • 2020 • Том 14/№ 4 • С. 69-84 
Padiomeлеметрія (radiotelemetry). Для відстежування активності тварин, зокрема, земноводних, найчастіше використовують радіотелеметрію. Для правильної роботи необхідне відповідне обладнання, а саме:

- приймач (receiver), який можна налаштовувати на різну частоту хвиль (наприклад, R-1000 Telemetry Receiver можна налаштувати на частоту діапазоном 148-174 мГц, ціна 670 \$);

- зазвичай використовують два типи антен: антена "хвильового каналу" (або антена Яги (Yagi antenna) чи антена Уда-Яги) а також Н-антена (яка є трохи простішою та швидше реагує на сигнал передавача);

- передавачі (transmitters), які бувають зовнішніми (типу “рюкзак") і внутрішніми (імплантуються під шкіру тварини).

Механізм роботи такий: на тварину прикріплюють передавач, який, працюючи на ультракоротких радіохвилях (142-230 мГц) [7]), у подальшому можна знайти з використанням антени та приймача (який налаштовують відповідно до робочої частоти мітки).

Передавач. Для дослідження земноводних використовують два типи передавачів: зовнішній і внутрішній.

Зовнішні передавачі прикріплюють до спини тварини за допомогою ремінців. Зазвичай використовують два типи кріплення, а саме рюкзак (рис. 1A) та перев'язування (рис. 1Б). У зовнішніх передавачів $€$ певні недоліки:

- часом сповзають з тварини;

- якщо неправильно розраховано співвідношення ваги амфібії та передавача (бажана вага передавача 3-5 \% та не більше 10 \% від ваги тіла тварини [18, 26]), це може призвести до травмування у видів із делікатною шкірою (наприклад, квакша або жаба трав'яна) чи навіть смерті [18];

- травмування ймовірне через зовнішню антену передавача, яка може зачепитися за рослинність [34];

- виникає певний дисбаланс у співвідношенні статей у дослідженні, оскільки такий датчик, встановлений на самицю до нересту, створюватиме певні труднощі для амплексуса та навіть ризик смерті самиці.
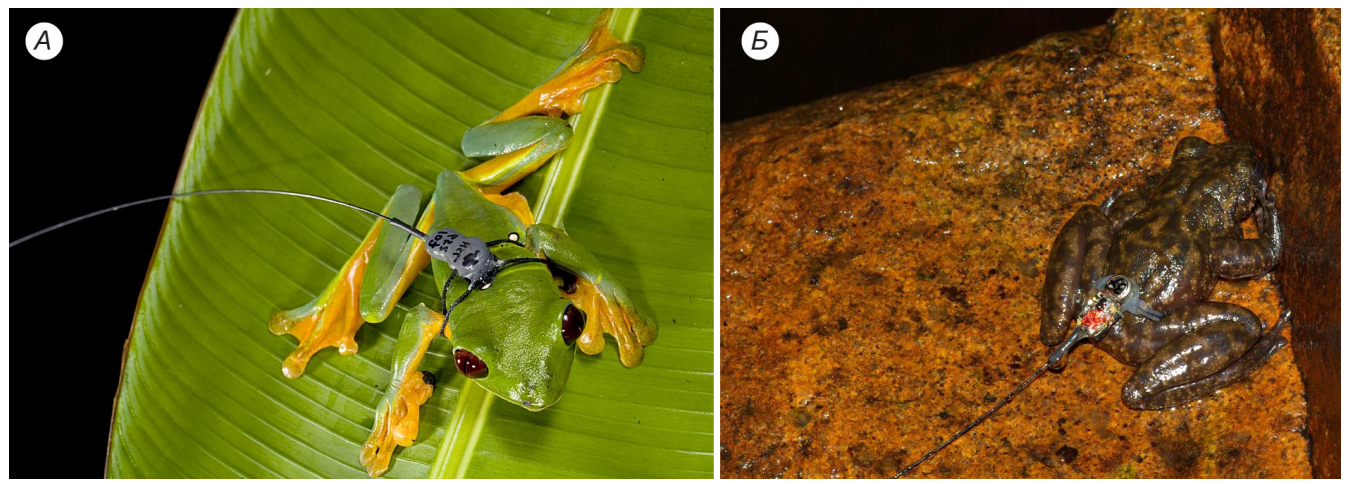

Рис. 1. Типи кріплення передавача (фото взято зі сайту https://www.holohil.com/)

Fig. 1. Types of transmitter mounting (pictures were taken from the website https://www.holohil.com/)

Внутрішній тип передавача розташовують під шкірою тварини. Матеріал (епоксидні смоли, парафін, бджолиний віск, термопластик, нереактивний бутилкаучук),

ISSN 1996-4536 (print) • ISSN 2311-0783 (on-line) • Біологічні Студії / Studia Biologica • 2020 • Том 14/№ 4 • С. 69-84 
яким покривають такі передавачі, є нетоксичним і максимально нейтральним для імунної системи тварини. $€$ два варіанти імплантації внутрішнього передавача. Перший варіант - це підшкірне розташування (недоліки та ризики для тварини зсування передавача, травмування і стирання шкіри в місці, де імплантовано передавач, особливо не рекомендовано для хвостатих). Другий варіант - внутрішньопорожнинне. Такий варіант імплантації потребує певних навичок проведення операції з використанням анестезії, накладанням шва та подальшим доглядом за раною $[26,34]$.

Ще одним варіантом імплантації такого передавача $€$ розташування його у травній системі як таблетки (gastric pill), котра природним чином вийде через 16-25 днів. Проте необхідно дуже точно розрахувати розмірні співвідношення такої “таблетки" та особини, аби передавач зміг достатньо легко пройти через травну систему [57].

$€$ чимало електронних ресурсів, де можна підібрати обладнання для трекінгу ${ }^{1}$ або ж подати заявку на отримання гранту з обладнанням для радіотрекінгу².

Радіотелеметрія буває автоматичною (automated radiotelemetry system), проте для цього необхідно використовувати спеціальне обладнання: приймачі (оснащені кількома антенами, які розташовані в різні сторони на $360^{\circ}$ ) та спеціальні передавачі. Інформація про активність особини автоматично зчитується потужними приймачами, які розміщені стаціонарно. 3 використанням такого підходу можна проводити моніторинг кількох видів одночасно на певній території [25].

Пошук гармонічного напрямку (harmonic direction finding). Спеціальна мітка - "гармонічна" (harmonic tag) - не потребує використання батареї, а тому має малу вагу (від 0,13 г для особини вагою мінімум 1,3-2,6 г [19]). Її навіть застосовують для трекінгу комах [52]. Прикріплення аналогічне, як у радіотелеметрії, також $\epsilon$ спеціальні кріплення для хвостатих земноводних [4]. Метод уперше застосовано у 60-70 рр. XX ст. для комах і вдосконалено у 1986 р. [32]. Спершу система такого трекінгу була розроблена для пошуку людей під сніговими лавинами шведською фрірмою Recco ${ }^{3}$.

Основою методу $є$ використання мітки та пеленгатора (harmonic direction finders), який виконує функцію детектора й випромінювача. Пеленгатор випромінює радіохвилі на УКХ частоті - 870 мГц, які, потрапляючи на мітку, подвоюються і зумовлюють власну генерацію радіохвиль міткою [46]. Для підвищення ефективності відбиття мітка обладнана антеною, довжина якої $є$ критичною для діапазону виявлення (довша антена збільшує діапазон) [32]. Через відсутність батареї таку мітку можна використовувати необмежено тривалий час, оскільки немає потреби у живленні. Ще однією перевагою є низька ціна мітки 5 \$ чи ще дешевше [28, 44, 55], хоча ціна пеленгатора значно більша за ціну приймачів, що використовуються у радіотелеметрії 6500 \$28]. Недоліком $€$ те, що всі мітки подають однаковий сигнал, а це не дає змоги безпосередньо по радіосигналу розрізняти мічених особин, тому варто заздалегідь продумати схему мічення особин. Крім того, дальність

\footnotetext{
1 https://atstrack.com/tracking-systems.html - сайт із описами різних методик трекінгу

2 Програма для отримання грантів з обладнанням для радіотрекінгу - https://www.holohil.com/

3 Шведська фрірма Recco після вдосконалення методу для пошуку людей під лавинами практично стала монополістом у виготовленні високоточних пеленгаторів, які, незважаючи на високу ціну, також використовують для трекінгу тварин. https://recco.com/history/
}

ISSN 1996-4536 (print) • ISSN 2311-0783 (on-line) • Біологічні Студії / Studia Biologica • 2020 • Том 14/№ 4 • С. 69-84 
виявлення такої мітки є меншою ( 15-20 м), ніж, наприклад, при радіотелеметрії, особливо у біотопах зі складним рельєфом [56]. Метод часто використовують для відстежування дрібних видів земноводних і ювенільних особин, а також для аналізу поведінки та преференцій у використанні біотопів [3-5, 15, 28, 29, 44, 46, 55, 56]. Цікавою особливістю обох описаних методів $€$ можливість виготовити все необхідне обладнання для трекінгу власноруч. У відкритому доступі $є$ чимало відеороликів ${ }^{4}$ і наукових публікацій $[19,40,46]$ де можна знайти покрокові інструкції/схеми з виготовлення міток чи навіть пеленгаторів.

Радіочастотний трекіне (Radio Frequency Identification, FRID). Мітки з ідентифрікацією радіочастот (Radio Frequency Identification, RFID) - це невеликі пристрої, які використовують радіохвилі малої потужності для прийому, зберігання та передачі даних до пристроїв зчитування поблизу. Передавачі складаються з таких основних компонентів: мікрочипа або інтегральної схеми, антени та шару основи або захисного матеріалу, який утримує всі компоненти разом. $€$ три основних типи RFID-тегів: пасивний, напівпасивний і активний з використанням акумулятора. Пасивні RFID-мітки не мають внутрішнього джерела живлення, вони живляться від електромагнітної енергії, що передається від приймача RFID. Через відсутність батареї й антени пасивні мітки бувають найменшими, але і діапазон дії у таких міток малий (до кількох метрів). Активні RFID-мітки мають власний передавач і джерело живлення в самій мітці. Напівпасивні, або акумуляторні мітки складаються з джерела живлення, включеного в конфігурацію пасивного тегу. Крім того, теги RFID 5 працюють у трьох частотних діапазонах: довгі радіохвилі (30-300 кГц), короткі радіохвилі (3-30 Мгц) і дециметрові радіохвилі (300 мГц - 3 гГц) [7]. У побуті аналогічні мітки використовують для чипування сільськогосподарських тварин, у домофронних ключах, біометричних документах тощо.

Для трекінгу земноводних використовують саме довгі радіохвилі, на яких працює пасивний інтегрований транспондер- PIT (Passive Integrated Transponder tags). Метод першочергово випробуваний на рибах для відстежування міграційної активності [48]. Проте з часом РІТ-мітки почали використовувати для відстежування міграцій інших груп тварин, таких як ссавці [58], птахи [9], рептилії [8], амфібії $[22,23]$, та навіть безхребетні [47]. Суть методу полягає у використанні спеціальної міні-мітки різної форми, залежно від досліджуваного виду (8-32 мм завдовжки та приблизно 1-4 мм у діаметрі [59]), яку вводять спеціальним шприцом чи хірургічним методом під шкіру, в м'язи чи в порожнину тіла тварини (рис. 2). У цьому разі тварину знеболюють, наприклад, зануривши на $~ 5$ хв у розчин гвоздичної олії (0,025 мл 100\% екстракту олії та 400 мл дехлорованої води) [65]. Часто після імплантації мітки за твариною спостерігають певний час і у разі ненормальної поведінки мітку видаляють. Неправильне розташування/імплантація мітки може призводити до її втрати, помилкового зчитування або ж до нечитабельності чи навіть до смерті особини. Правильно встановлена РІТ-мітка жодним чином не впливає на особину (є дослідження, де встановлено, що так помічені особини рухаються швидше від тих, які помічені радіопередавачами [10]), і дає змогу отримувати

4 Спортивна радіопеленгація, також відома під назвою “полювання на лисицю”. Це група спортивних дисциплін радіоспорту. За цими назвами можна знайти чимало корисного матеріалу для самостійного виготовлення обладнання

5 Посилання на сайт, де можна знайти різного типу RFID-мітки та необхідне обладнання для трекінгу https://www.atlasrfidstore.com/rfid-tags/

ISSN 1996-4536 (print) • ISSN 2311-0783 (on-line) • Біологічні Студії / Studia Biologica • 2020 • Том 14/№ 4 • С. 69-84 
достатньо точні дані [11]. Така мітка - це електронний мікрочип, антена та конденсатор, укладені у біосумісне скло, яка зберігатиме унікальний код, присвоєний особині на все її життя $[17,59]$. Такий код часто прирівнюють до відбитків пальців, який є унікальним і постійним. Також РІТ-мітка не потребує батареї, має маленьку вагу і розміри, тому може бути використана для дрібних тварин [59].
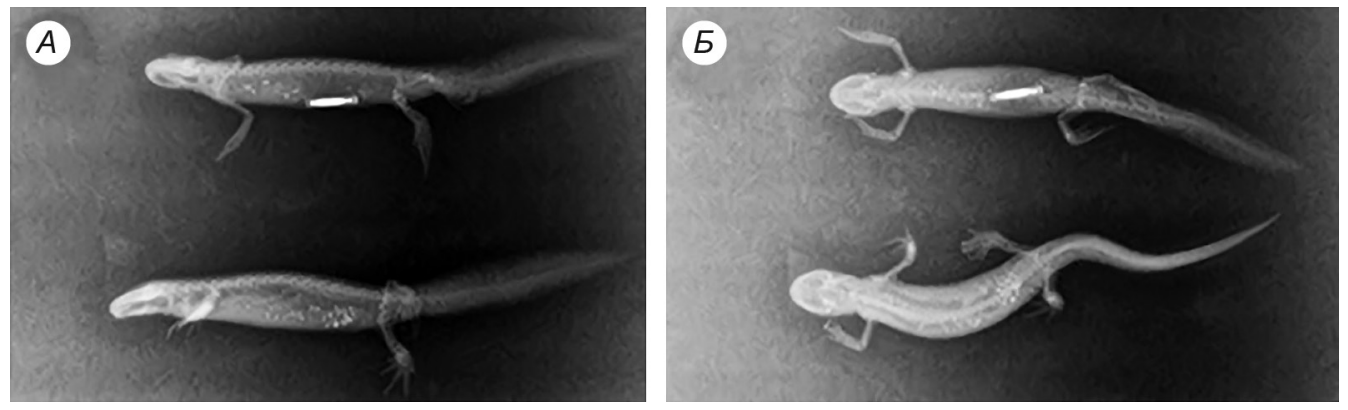

Рис. 2. Рентгенологічні зображення двох тритонів гребінчастих Triturus cristatus у бічному $(\boldsymbol{A})$ та спинному (Б) положенні. Верхній тритон - самець із міткою РІT, нижній тритон - самка без мітки PIT [65]

Fig. 2. X-ray images of two Triturus cristatus in lateral $(\boldsymbol{A})$ and in dorsal $(\boldsymbol{E})$ position. The upper newt is a male with a PIT tag, the lower newt is a female without PIT tag [65]

Слово “пасивний” (рassive) означає, що мітка є неактивною між зчитуванням. Зчитування відбувається завдяки генеруванню зчитувачем електромагнітного поля, коли мітка перебуває поруч, проте обоє (мітка та зчитувач) мають працювати на одних частотах (розбіжність частот є причиною незчитування мітки) [17]. Для зчитування не обов'язково відловлювати особину, достатньо, аби вона пройшла повз антену автоматичного зчитування. Часто для відстежування міграцій земноводних використовують системи різних антен, які розташовані на рівних відстанях [10]. А під час проходження тварини повз таку систему антена зчитує універсальний номер мітки, присвоєний особині. Такі антени також можна конструювати самостійно, користуючись відповідними літературними джерелами. Розпочати пошук варто з роботи групи науковців зі штату Массачусетс (США) [10], де чітко описано, як відбувалося конструювання двох типів антен для відстежування міграції Ambystoma maculatum, Notophthalmus viridescens, Hemidactylium scutatum та Rana sylvatica. Проте конструкція таких систем антен є дорогою. Кожна мітка коштує приблизно 0,77 \$6. Більшість зчитувачів коштують від 800 до 1500 , залежно від виробника й технічних особливостей ${ }^{7}$.

Метод активно використовують для оцінювання ефективності ренатуралізації видів [20], дослідження їхнього поширення, пошуку кормових біотопів і оцінювання їхнього використання, швидкості росту, виживання [59], денної активності й характеру руху особин різної статі [65], під час оцінювання використання підземних

6 На час написання публікації мітка, яку часто використовують для дрібних тварин (MiniHPT8), на сайті виробника коштує 7,65 \$ за упаковку з 10 шт. https://www.biomark.com/minihpt8-pre-load-sterile

7 Список основних виробників систем, а також адреси їхніх веб-сайтів наведено нижче:

- Biomark, Inc.: www.biomark.com; Meridian, Idaho.

- Digital Angel Corporation (formerly Destron Fearing, Inc.): www.destronfearing.com; St. Paul, Minnesota.

- Trovan, Ltd.: www.trovan.com; Santa Barbara, California 
захисних бар'єрів [63], пошуку нерестилищ або місць гібернації [1], використання особиною території проживання [43], під час боротьби з нелегальною торгівлею тваринами [17] тощо.

Флуоресцентний порошок (fluorescent powder). Наступний метод відстежування пересування земноводних полягає у використанні спеціального фрлуоресцентного порошку. Найкраще метод застосовувати на дрібних ссавцях - на їхній шерсті порошок добре затримується, і сліди пересування можна знаходити протягом кількох ночей [36], проте цей метод також успішно використовують із земноводними та рептиліями $[2,14,49,53]$. Метод полягає у нанесенні фрлуоресцентного порошку (є різні кольори) на поверхню тіла тварини, яку після цього відпускають. Сліди пересування можна виявити вночі з використанням спеціальної ультрафріолетової лампи. Основна складність у використанні цього методу - це правильний підбір порошку. Б. Віндмілер [66] припускав негативний вплив використання фрлуоресцентного порошку на земноводних через зменшення маси тіла, зміни у поведінці особини та, можливо, смертність. Проте група науковців [53], які провели дослідження впливу флуоресцентного порошку на ювенільних особин Ambystoma maculatum i Rana sylvatica, заперечують шкідливий вплив порошку на амфрібій [42, 54]. Небезпекою $є$ тільки те, що тварина після використання флуоресцентного порошку є більш помітною вдень і вночі для хижаків, які здатні бачити в ультрафіолетовому діапазоні світла [54]. Наступним питанням $€$ нещодавнє відкриття про біофрлуоресценцію земноводних, яка сприяє виявленню особин протилежної статі вночі під час нересту [27]. Вплив фрлуоресцентного порошку на процес розмноження досі не досліджений. Під час використання фрлуоресцентного порошку варто пам'ятати, що земноводні в основному торкаються субстрату кінцівками та черевом (як і хвостом), тому немає потреби повністю покривати тварину порошком. Погодні умови (туман, дощ, висока вологість) можуть впливати на збереження слідів, тому рекомендується відстежувати їх без зволікань [35]. Та й, зрештою, сліди від фрлуоресцентного порошку зберігаються досить коротко (протяжність, на яку вистачає порошку, приблизно 100 м, і найкраще відстежувати особину перші 3 год) $[2,13]$. Метод протестовано на значній кількості видів земноводних, які використовують різні типи біотопів, і він виявився безпечним і найменш інвазійним із усіх описаних [13, 33].

Нитковий трекіне (spool tracking). Це використання котушки нитки, яку прикріплюють до тварини [30, 37]. Метод поєднує простоту і доступність із відносно низькою ціною $[36,64]$ та навіть із можливістю самостійного виготовлення такої котушки [62]. Для хорошого дизайну експерименту необхідно розуміти добову активність досліджуваного об'єкта й коректно підібрати необхідну довжину нитки [38]. Ймовірна зупинка тварини через закінчення нитки може призвести до загибелі тварини. Необхідно брати до уваги і вагу самої тварини, аби котушка не була занадто важкою чи великою. Під час вибору котушки працює те ж правило: менше 10 \% від ваги тварини, як і за інших методів трекінгу $[18,26]$. Не менш важливо помістити котушку в пластикову капсулу, яка захистить нитку від намокання чи зачіпання за рослини. Якщо відпустити тварину перед нерестом або якщо біологія тварини після нересту пов'язана з водоймою, необхідно забезпечити спеціальну капсулу для нитки (яку саме - описано у [18]). Важливо, аби така капсула мала отвір з одного боку, де буде виходити нитка (рис. 3). Вільний край нитки прив'язують до певної стаціонарної основи (дерево, чагарник тощо) і випускають тварину. Для

ISSN 1996-4536 (print) • ISSN 2311-0783 (on-line) • Біологічні Студії / Studia Biologica • 2020 • Том 14/№ 4 • С. 69-84 
зручності пошуку місця відліку варто взяти до уваги певне маркування, оскільки пізніше, наприклад, у лісі, дуже легко загубити місце, де було випущено тварину. Можна використати яскраві прапорці, тканини, прив'язані до цього ж дерева, чи будь-що інше, і про це варто подумати заздалегідь. Виписування координат такого місця може бути не настільки ефективним, оскільки більшість доступних пристроїв (смартфон чи недорогі GPS-трекери) матимуть певну похибку і проблему з пошуком супутників, наприклад, у лісі, якої може бути достатньо для того, аби експериментатор довго шукав місце вивільнення тварини. Для мінімізування стресу тварину необхідно випускати приблизно у цьому ж місці, де її було відловлено, і не пізніше 48 год від вилучення ії зі середовища та 2 год від прикріплення до неї котушки. Такого ж алгоритму варто дотримуватися і під час використання решти методів трекінгу.

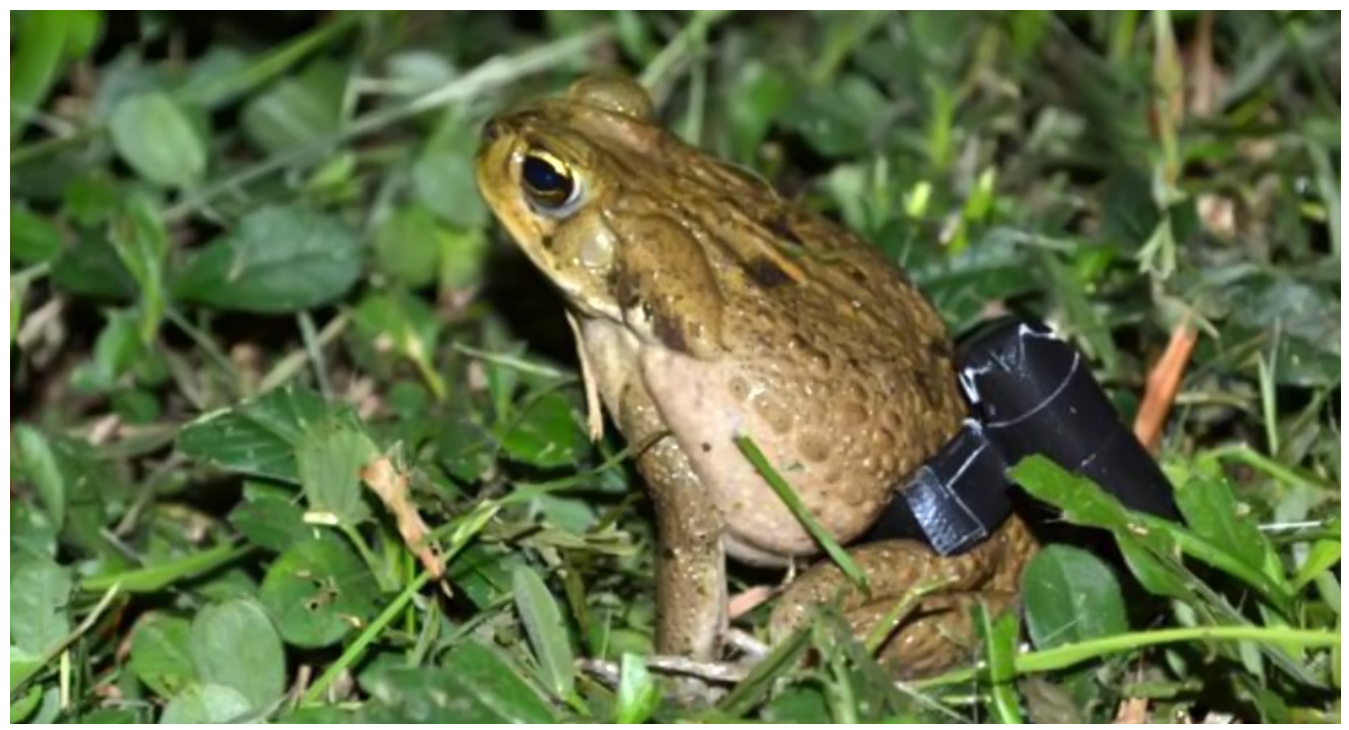

Рис. 3. На фото представлено варіант кріплення котушки з ниткою навколо тазового відділу безхвостих (фото Emily Waddell) [64]

Fig. 3. The frog with thread spool attached to it's rump (photo Emily Waddell) [64]

Надалі перевірка локалізації й активності тварини залежить від поставленого питання та вашого завдання. Якщо довжина нитки недостатня для охоплення добової активності тварини, тоді краще частіше перевіряти стан тварини і чи не зупинила особину довжина нитки (наприклад, кожні 12 год). У літературних джерелах $[18,64]$ наведено, як саме можна побудувати свій експеримент із мінімальною шкодою для тварини. Також варто мати на увазі, що шкіра у деяких видів земноводних досить делікатна, а під час інтенсивних стрибків (для України це всі жаби родини Ranidae, також чутливими є квакші через вертикальні підйоми) довге використання котушок може викликати натирання шкіри чи спричиняти синяки, тому цей метод трекінгу не варто довго використовувати [12]. У минулому столітті застосовували досить великі котушки (рис. 4). Проте травмування тварини значно меншими котушками також спостерігають [18]. Трохи стійкішими до використання котушок будуть ропухи завдяки цупкій і товстій шкірі [51].

ISSN 1996-4536 (print) • ISSN 2311-0783 (on-line) • Біологічні Студії / Studia Biologica • 2020 • Том 14/№ 4 • С. $69-84$ 


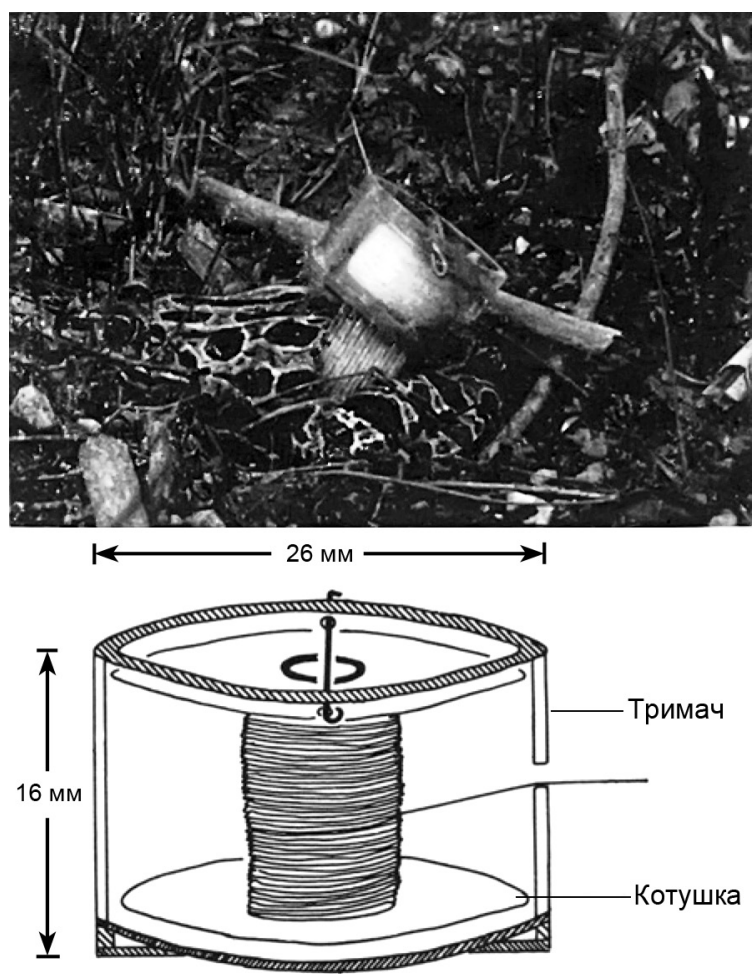

Рис. 4. Котушка нитки для трекінгу Rana pipiens, використана Джимом Доле [12]

Fig. 4. Thread spool used for tracking of Rana pipiens by Jim Dole [12]

Зважаючи на простоту методу, він залишається найдоступнішим і дешевим для використання.

Кожен із вищеописаних методів ${ }^{8}$ дає змогу відстежувати активність тварини і таким чином дізнаватися більше про особливості поведінкової біології виду.

\section{ВИСНОВОК}

Використання сучасних методів трекінгу дає змогу відповісти на значну кількість запитань. Проте, на жаль, це досі вартісні методи для широкого використання (табл. 2) українськими герпетологами. Аналіз літературних джерел довів, що є достатня кількість відкритого матеріалу з практично покроковими інструкціями для самостійного виробництва обладнання для таких методів трекінгу як, наприклад, радіотелеметрія чи радіочастотний метод.

Для систематизації та лаконічності в табл. 2 представлено відповіді на основні питання, які можуть виникати під час підбору методу трекінгу та побудови дизайну експерименту.

8 Сайти з корисною інформацією про трекінг і обладнання (не тільки для земноводних):

http://www.locateiii.com/

http://www.argos-system.org/

http://www.biotrack.co.uk/

http://www.sirtrack.com/

http://www.telonics.com/

http://www.biomark.com/

http://www.holohil.com/

ISSN 1996-4536 (print) •ISSN 2311-0783 (on-line) • Біологічні Студії / Studia Biologica • 2020 • Том 14/№ 4 • C. 69-84 


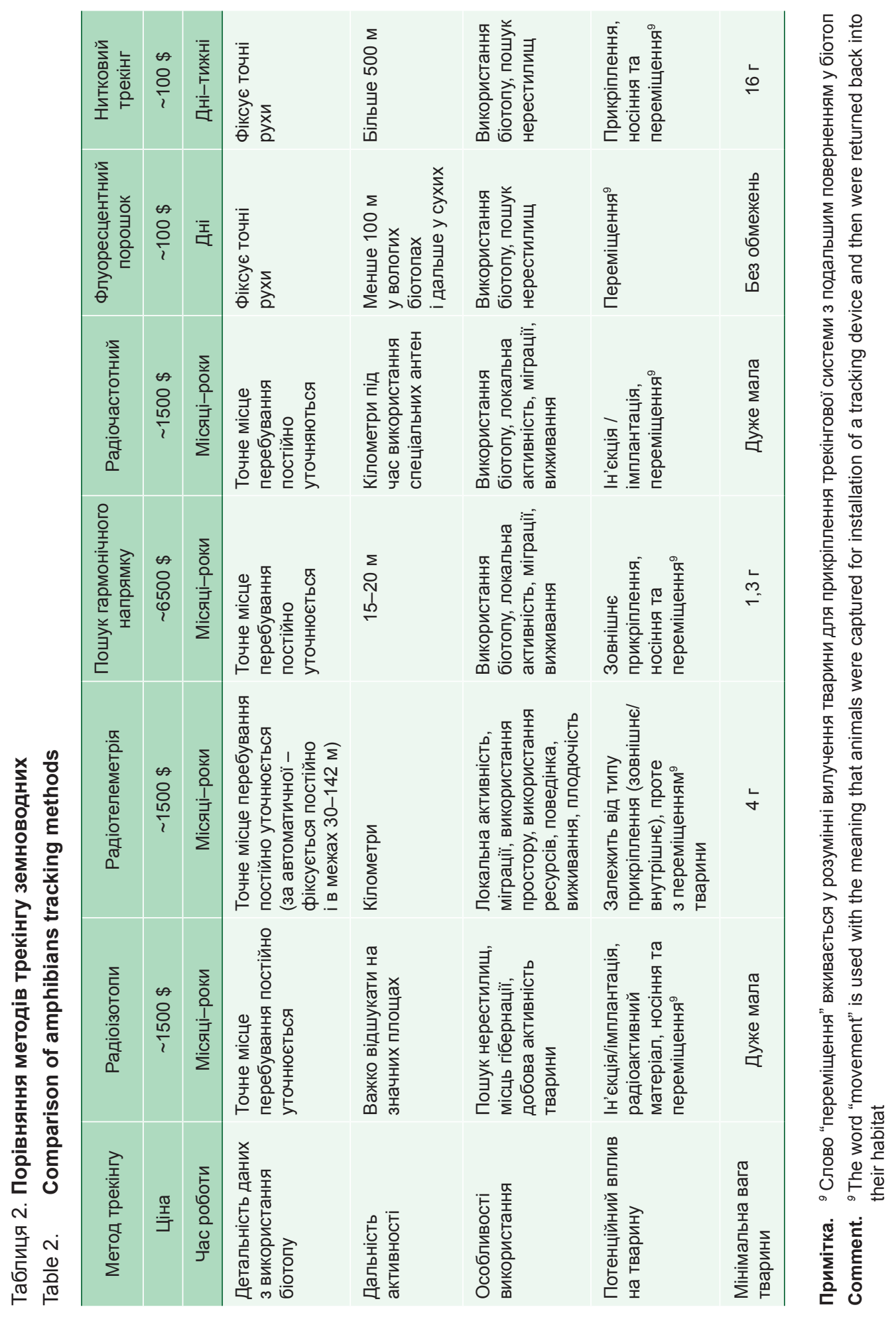

ISSN 1996-4536 (print) • ISSN 2311-0783 (on-line) • Біологічні Студії / Studia Biologica • 2020 • Том 14/№ 4 • С. 69-84 


\section{COMPLIANCE WITH ETHICAL STANDARDS}

Conflict of Interest: The authors declare that the research was conducted in the absence of any commercial or financial relationships that could be construed as a potential conflict of interest.

Human Rights: This article does not contain any studies with human subjects performed by the any of the authors.

Animal studies: All institutional, national and institutional guidelines for the care and use of laboratory animals were followed.

1. Atkinson-Adams M.R., Price C.J., Scrimgeour G.J., Paszkowski C.A. Long-toed Salamander (Ambystoma macrodactylum) hibernacula in Waterton Lakes National Park revealed using Passive Integrated Transponder telemetry. Canadian Field-Naturalist, 2018; 132(2): 168-175.

Crossref $\bullet$ Google Scholar

2. Birchfield G., Deters J. Movement paths of displaced northern green frogs (Rana clamitans melanota). Southwest. Nat., 2005; 4: 63-76.

Crossref $\bullet$ Google Scholar

3. Borzée A., Kim J.Y., da Cunha M.A.M., Lee D., Sin E., Oh S., Yi Y., Jang Y. Temporal and spatial differentiation in microhabitat use: Implications for reproductive isolation and ecological niche specification. Integrative Zoology, 2016; 11: 375-87.

Crossref $\bullet$ PubMed $\bullet$ Google Scholar

4. Borzée A., Kim Y.I., Kim K., Jang Y. Methodological development for harmonic direction finder tracking in salamanders. Herpetological Conservation and Biology, 2018; 13(2): 473-478.

Google Scholar

5. Borzée A., Choi Y., Kim Y.E., Jablonski P.G., Jang Y. Interspecific variation in seasonal migration and brumation behavior in two closely related species of treefrogs. Front. Ecol. Evol., 2019; 7: 55.

Crossref $\bullet$ Google Scholar

6. Breckenridge W.J., John R.T. Growth, local movements and hibernation of the manitoba toad, Bufo hemiophrys. Ecology, 1961; 42(4): 637-646.

Crossref $\bullet$ Google Scholar

7. Breed M.D., Moore J. Encyclopedia of Animal Behavior. 3th Ed. In: Pinter-Wollman N., Mabry K.E. (Ed.) Remote-Sensing of Behavior. Oxford: Academic Press, 2010. P. 33-40. Crossref $\bullet$ Google Scholar

8. Buhlmann K.A., Tuberville T.D. Use of passive integrated transponder (PIT) tags for marking small freshwater turtles. Chelonian Conservation and Biology, 1998; 3(1): 102-104.

Google Scholar

9. Carver A.V., Burger Jr.L.W., Brennan L.A. Passive integrated transponders and patagial tag markers for northern bobwhite chicks. The Journal of Wildlife Management, 1999; 63(1): 162-166.

Crossref $\bullet$ Google Scholar

10. Charney N., Letcherd B., Haro A., Warren P. Terrestrial passive integrated transponder antennae for tracking small animal movements. Journal of Wildlife Management, 2009; 73: 1245-1250.

Crossref $\bullet$ Google Scholar

11. Connette G.M., Semlitsch R.D. Successful use of a passive integrated transponder (PIT) system for below-ground detection of plethodontid salamanders. Wildlife Research, 2012; 39(1): 1-6.

Crossref $\bullet$ Google Scholar

12. Dodd C.K. Jr. Amphibian ecology and conservation. A handbook of techniques. New York, USA: Oxford University Press, 2009. 556 p.

Google Scholar

ISSN 1996-4536 (print) • ISSN 2311-0783 (on-line) • Біологічні Студії / Studia Biologica • 2020 • Том 14/№ 4 • С. 69-84 
13. Dole J.W. Summer movements of adult Leopard Frogs, Rana pipiens (Schreber), in northern Michigan. Ecology, 1965; 46: 236-255.

Crossref $\bullet$ Google Scholar

14. Eggert $C$. Use of fluorescent pigments and implantable transmitters to track a fossorial toad (Pelobates fuscus). Herpetological Journal, 2002; 12: 69-74. Google Scholar

15. Fellers G.M., Drost C.A. Fluorescent powder: A method for tracking reptiles. Herpetological Review, 1989; 20: 91-92. Google Scholar

16. Fischer M., Ringler M., Ringler E., Pašukonis A. Reproductive behavior drives female space use in a sedentary Neotropical frog. PeerJ, 2020; 8: e8920.

Crossref $\bullet$ PubMed $\bullet$ Google Scholar

17. Gerrard M. Tagging of small animals with radioisotopes for tracking purposes: a literature review. International Journal of Apphed Radiation and Isotopes, 1969; 20: 671-676.

Crossref $\bullet$ Google Scholar

18. Gibbons J.W., Andrews K.M. PIT tagging: simple technology at its best. BioScience, 2004; 54(5): 447-454.

Crossref $\bullet$ Google Scholar

19. Gourevitch E.H.Z., Downie J.R. Evaluation of tree frog tracking methods using Phyllomedusa trinitatis (Anura: Phyllomedusidae). Phyllomedusa, 2018; 17(2): 233-246.

Crossref $\bullet$ Google Scholar

20. Gourret A., Alford R., Schwarzkopf L. Very small, light dipole harmonic tags for tracking small animals. Herpetological Review, 2011; 42(4): 522-525.

Google Scholar

21. Hammond T.T., Curtis M.J., Jacobs L.E., Tobler M.W., Swaisgood R.R., Shier D.M. Behavior and detection method influence detection probability of a translocated, endangered amphibian. Animal Conservation, 2020.

Crossref $\bullet$ Google Scholar

22. Heyer W.R., Donnelly M.A., McDiarmid R.W., Hayek L.A.C., Foster M.S. In Measuring and Monitoring Biological Diversity: Standard Methods for Amphibians. In: Ashton R.E. Jr. (Ed.) Tracking with radioactive tags. Smithsonian Institution Press, 1994: 158-163.

Google Scholar

23. Jehle R., Hödl W. PITs versus patterns: effects of transponders on recapture rate and body condition of Danube crested newts (Triturus dobrogicus) and common spadefoot toads (Pelobates fuscus). Herpetological Journal, 1998; 8: 181-186.

Google Scholar

24. Jehle R., Arntzen J.W. Post-breeding migrations of newts (Triturus cristatus and T. marmoratus) with contrasting ecological requirements. Journal of Zoology, London, 2000; 251: 297-396.

Crossref $\bullet$ Google Scholar

25. Karlstrom E.L. The Use of $\mathrm{Co}^{60}$ as a tag for recovering amphibians in the field. Ecology, 1957; 38(2): 188-195.

Crossref $\bullet$ Google Scholar

26. Kays R., Tilak S., Crofoot M., Fountain T., Obando D., Ortega A., Kuemmeth F., Mandel J., Swenson G., Lambert T., Hirsch B., Wikelski M. Tracking animal location and activity with an automated radio telemetry system in a tropical rainforest. The Computer Journal, 2011; 54(12): 1931-1948.

Crossref $\bullet$ Google Scholar

27. Lamb J.Y., Davis M.P. Salamanders and other amphibians are aglow with biofluorescence.

Scientific Reports, 2020; 10: 2821.

Crossref $\bullet$ PubMed $\bullet$ Google Scholar

28. Langkilde T., Alford R.A. The tail wags the frog: Harmonic radar transponders affect movement behavior in Litoria lesueuri. Journal of Herpetology, 2002; 36(4): 711-715.

Crossref • Google Scholar

29. Leskovar $C$., Sinsch U. Harmonic direction finding: a novel tool to monitor the dispersal of small-sized anurans. The Herpetological Journal, 2005; 15: 173-180.

Google Scholar

ISSN 1996-4536 (print) •ISSN 2311-0783 (on-line) • Біологічні Студії / Studia Biologica • 2020 • Том 14/№ 4 • C. 69-84 
30. Madison D.M., Shoop C.R. Homing behavior, orientation, and home range of salamanders tagged with tantalum-182. Science, 1970; 168(3938): 1484-1487.

Crossref $\bullet$ PubMed $\bullet$ Google Scholar

31. Madison D. M., Farrand L. Habitat use during breeding and emigration in radio-implanted tiger salamanders, Ambystoma tigrinum. Copeia, 1998; 1998(2): 402-410.

Crossref $\bullet$ Google Scholar

32. Mascanzoni $D$., Wallin $H$. The harmonic radar: a new method of tracing insects in the field. Ecological Entomology, 1986; 11(4): 387-390.

Crossref $\bullet$ Google Scholar

33. Matos C., Petrovan S.O., Wheeler P.M., Ward A.I. Short-term movements and behaviour govern the use of road mitigation measures by a protected amphibian. Animal Conservation, 2019; 22(3): 285-296.

Crossref $\bullet$ Google Scholar

34. McAllister K.R., Watson J., Risenhoover K., McBride T. Marking and radiotelemetry of Oregon spotted frogs (Rana pretiosa). Northwestern Naturalist, 2004; 85(1): 20-25.

Crossref $\bullet$ Google Scholar

35. McDiarmid R.W., Foster M.S., Guyer C., Gibbons J.W., Chernoff N. Raptile biodiversity: Standard methods for inventory and monitoring. London: University of Callifornia Press, 2012. 424 p.

Google Scholar

36. Mellor D.J., Beausoleil N.J., Stafford K.J. Marking amphibians, reptiles and marine mammals: animal welfare, practicalities and public perceptions in New Zealand. Wellington, New Zealand: Department of Conservation, 2004. 55 p. Google Scholar

37. Miles M.A. A simple method of tracking mammals and locating triatomine vectors of Trypanosoma cruzi in Amazonian forest. The American Journal of Tropical Medicine and Hygiene, 1976; 25(5): 671-674.

Crossref $\bullet$ PubMed $\bullet$ Google Scholar

38. Miles M.A. Mammal tracking and nest location in Brazilian forest with an improved spool-andline device. Journal of Zoology, 1981; 195(3): 331-347.

Crossref • Google Scholar

39. Mullican T.R. Radio telemetry and fluorescent pigments: a comparison of techniques. The Journal of Wildlife Management, 1988; 52(4): 627-631. Crossref • Google Scholar

40. Naef-Daenzer B. Fruth D., Stalder M., Welti P., Weise E. Miniaturisation $(0.2 \mathrm{~g})$ and evaluation of attachment techniques of telemetry transmitters. Journal of Experimental Biology, 2005; 208: 4063-4068.

Crossref • PubMed • Google Scholar

41. Okamiya H., Kusano T. Evaluating movement patterns and microhabitat selection of the japanese common toad (Bufo japonicus formosus) using fluorescent powder tracking. Zoological Science, 2018 35(2): 153-160.

Crossref $\bullet$ PubMed $\bullet$ Google Scholar

42. Orlofske S.A., Grayson K.L., Hopkins W.A. The Effects of fluorescent tracking powder on oxygen consumption in salamanders using either cutaneous or bimodal respiration. Copeia, 2009; 2009(3): 623-627.

Crossref $\bullet$ Google Scholar

43. Ousterhout B.H.. Burkhart J.J. Moving beyond the plane: measuring 3D home ranges of juvenile salamanders with passive integrated transponder (PIT) tags. Behavioral Ecology and Sociobiology, 2017; 71(59).

Crossref $\bullet$ Google Scholar

44. Pašukonis A., Warrington I., Ringler M., Hödl W. Poison frogs rely on experience to find the way home in the rainforest. Biology Letters, 2014; 10: 20140642.

Crossref $\bullet$ PubMed $\bullet$ Google Scholar

45. Patt $H$., Swift $M$. Influence of temperature on the response of frogs to $\mathrm{X}$ irradiation. Amer. J. Physiol., 1948; 155(3): 388-393.

Crossref $\bullet$ PubMed $\bullet$ Google Scholar

ISSN 1996-4536 (print) • ISSN 2311-0783 (on-line) • Біологічні Студії / Studia Biologica • 2020 • Том 14/№ 4 • С. 69-84 
46. Pellet J., Rechsteiner L., Skrivervik A.K., Zurcher J.F., Perrin N. Use of the harmonic direction finder to study the terrestrial habitats of the european tree frog (Hyla arborea). AmphibiaReptilia, 2006; 27: 138-142.

Crossref $\bullet$ Google Scholar

47. Pengilly D., Watson L.J. Automated detection of internally injected tags in red king crabs at crab processing facilities. Fisheries Research, 1994; 19: 93-300. Crossref $\bullet$ Google Scholar

48. Prentice E.F., Park D.L. (Ed.) A study to determine the biological feasibility of a new fish tagging system. Annual Report of Research. Seattle, Washington, 1983. 43 p. Google Scholar

49. Ramírez P.A., Bell B.D., Germano J.M., Bishop P.J., Nelson N.J. Tracking a small cryptic amphibian with fluorescent powders. New Zealand Journal of Ecology, 2017; 41(1): 134-138. Crossref $\bullet$ Google Scholar

50. Reshetylo O., Stakh V., Osiyeva A.-A., Dykyy I., Andriyishyn B., Panchuk M., Tsaryk I. Mortality of amphibians on the roads of Lviv province (Ukraine): trend for the last decade. Vestnik Zoologii, 2019; 53 (2): 131-140.

Crossref $\bullet$ Google Scholar

51. Reshetylo O., Strus V., Andriishyn B. A field key for the identification of amphibians killed on the roads. Lviv: Ivan Franko National University of Lviv, 2020. 42 p.

52. Riley J.R., Valeur P., Smith A.D. et al. Harmonic radar as a means of tracking the pheromonefollowing flight of male moths. Journal of Insect Behavior, 1998; 11: 287-296.

Crossref • Google Scholar

53. Rittenhouse T.A.G., Altnethert. T. Fluorescent Powder pigments as a harmless tracking method for ambystomatids and ranids. Herpetological Review, 2006; 37(2): 188-191. Google Scholar

54. Roe A.W., Grayson K.L. Repeated exposure to fluorescent powder does not affectsurvival or mass in Eastern red-spotted newts, Notophthalmus viridescens. Applied Herpetology, 2009; 6(3): 295-299.

Crossref $\bullet$ Google Scholar

55. Roznik E.A., Alford R.A. Seasonal ecology and behavior of an endangered rainforest frog (Litoria rheocola) threatened by disease. PLoS One, 2015; 10(5): e0127851.

Crossref $\bullet$ PubMed $\bullet$ PMC $\bullet$ Google Scholar

56. Rowley J.J.L., Alford R.A. Techniques for tracking amphibians: The effects of tag attachment, and harmonic direction finding versus radio telemetry. Amphibia-Reptilia, 2007; 28(3): 367-376. Crossref $\bullet$ PubMed $\bullet$ Google Scholar

57. Schabetsberger R., Jehle R., Maletzky A., Pesta J., Sztatecsny M. Delineation of terrestrial reserves for amphibians: Post-breeding migrations of the Italian crested newt (Triturus $C$. carnifex) at high altitudes. Biological Conservation, 2004; 117: 95-104.

Crossref $\bullet$ Google Scholar

58. Schooley R.L., van Horne B., Burnham K.P. Passive integrated transponders for marking free-ranging townsend's ground squirrels. Journal of Mammalogy, 1993; 74(2): 480-484.

Crossref $\bullet$ Google Scholar

59. Smyth B., Silke N. Passive Integrated Transponder (PIT) tags in the study of animal movement. Nature Education Knowledge, 2013; 4(3): 3.

Google Scholar

60. Stearner S.P. The effect of X irradiation on Rana pipiens (leopard frog), with special reference to survival and the response of the peripheral blood. Journal of Experimental Zoology, 1950; 115: 251-262.

Crossref • Google Scholar

61. Stille W.T. The loss of jaw tags by toads. Chicago Nat. Hist. Mus., Nat. Hist. Misc., 1950; 74: 2 p. Google Scholar

62. Sutherland D., Glen A., Cruz J. An alternative spool-and-line tracking device for mediumsized animals. Australian Mammalogy, 2008; 30: 89-90.

Crossref $\bullet$ Google Scholar

63. Testud G., Vergnes A., Cordier P., Labarraque D., Miaud C. Automatic detection of small PITtagged animals using wildlife crossings. Anim Biotelemetry, 2019; 7: 21.

Crossref • Google Scholar

ISSN 1996-4536 (print) •ISSN 2311-0783 (on-line) • Біологічні Студії / Studia Biologica • 2020 • Том 14/№ 4 • C. 69-84 
64. Waddell E., Whitworth A., MacLeod R. A first test of the thread bobbin tracking technique as a method for studying the ecology of herpetofauna in a tropical rainforest. Herpetological Conservation and Biology, 2016; 11: 61-71.

Google Scholar

65. Weber L., Šmejkal M., Bartoň D., Rulík M. Testing the applicability of tagging the Great crested newt (Triturus cristatus) using passive integrated transponders. PLoS One, 2019; 14(7): e0219069.

Crossref $\bullet$ PubMed $\bullet$ Google Scholar

66. Windmiller $B$. Tracking techniques useful for field studies of anuran orientation and movement. Herpetological Review, 1996; 27: 13-15.

Google Scholar

\title{
METHODS OF AMPHIBIAN TRACKING
}

\author{
V. Strus ${ }^{1}$, Iu. Strus ${ }^{2,3}$ \\ ${ }^{1}$ Ivan Franko National University of Lviv, 4, Hrushevskyi St., Lviv 79005, Ukraine \\ 2 State Museum of Natural History, NAS of Ukraine, 18, Teatralna St., Lviv 79008, Ukraine \\ 3 "Roztochia" Nature Reserve, 7, Sichovyh Strilciv St., Ivano-Frankove, Lviv Region 81071, Ukraine \\ e-mail: vasylyna.stakh@Inu.edu.ua
}

Introduction: In this article, we present a literature review of modern, most common, and useful methods of amphibian tracking. Amphibians are the most sensitive group of animals and near $41 \%$ of species are under the risk of extinction. Therefore, the research of spatial movements of amphibians is one of the most topical tasks of modern herpetology. The information about the use of space is needed for practical protection of sensitive species of amphibians, for planning of protected areas, estimation of the potential danger for some groups of animals when designing infrastructure objects, such as roads. The movement studies gained popularity and have been undertaken since the second part of the 20th century. Such growth in the number of studies is related to the recent advances in radio-electronic technology that contributed to the creation of a range of instruments for automatic or semi-automatic tracking of individual animals. Unfortunately, most of such methods are still too expensive for scientists from developing countries. Thus, classical methods are still widely used.

Results: We describe six methods of amphibians tracking: radioisotope tracking, automated radio telemetry, harmonic direction finding, radio frequency identification, fluorescent powder, spool tracking. Each of these methods allows collecting detailed information about spatial movements of individuals. Many of these tracking methods require using of a special tag, which is attached to an animal and used for its further detection. Different types of tags have identical functions but are based on different principles of use. Two of the described methods do not require using of tags and are cheap. These are fluorescent powder and spool tracking. In the article, we provide many links to grant programs and places where special equipment can be found.

Conclusions: As a result of literature review, we created a table with concise information about all the described methods. Using this table one can choose the best method for an experiment.

Keywords: amphibians, radiotelemetry, fluorescent powder, radioisotope tracking, spool tracking

Received / Одержано 08 November 2020
Accepted / Прийнято 16 December 2020
Published / Опубліковано 29 December 2020

ISSN 1996-4536 (print) • ISSN 2311-0783 (on-line) • Біологічні Студії / Studia Biologica • 2020 • Том 14/№ 4 • С. 69-84 